\title{
GAMBARAN FOTO TORAKS PNEUMONIA DI BAGIAN/SMF \\ RADIOLOGI FK UNSRAT / RSUP PROF. DR. R. D KANDOU \\ MANADO PERIODE 1 APRIL - 30 SEPTEMBER 2015
}

\author{
${ }^{1}$ Nurpratiwi Langke \\ ${ }^{2}$ Ramli H. Ali \\ ${ }^{2}$ Martin L. Simanjuntak \\ ${ }^{1}$ Mahasiswa Fakultas Kedokteran Universitas Sam Ratulangi Manado \\ ${ }^{2}$ Bagian Radiologi Fakultas Kedokteran Universitas Sam Ratulangi Manado \\ Email : nlangke12207@gmail.com
}

\begin{abstract}
Background: acute lower respiratory tract Infections called (ISNBA) raises the number of pain and a high mortality and loss of productivity of work. ISNBA can be found in various forms, common is pneumonia. Pneumonia is a disease which many occurred that infects roughly 450 million people annually and occur throughout the world. This disease is a major cause of death in all groups that cause millions of deaths (7\% of world total deaths) each year. This figure is most occurred in children aged less than 5 years old, and adults who are over 75 years old. Chest X-ray is the modality used to diagnose many conditions involving the thoracic wall and thoracic bone structure, located in the thoracic kavitas including the lungs, heart and great channels.
\end{abstract}

Objective: to know the description of chest X-ray in people with pneumonia.

Methods: This research is descriptive research study was conducted on November 2015 in Radiology Devision Faculty of medical Sam Ratulangy University/ General Hospital Center Prof. Dr. R. D. Kandou Manado.

Results: there were 44 cases of pneumonia based on radiologic diagnosis. Most sufferers are male 24 people (55\%), the largest age group is as many as 60 years $>12$ people (27\%), and the location of most pneumonia in pulmo dextra 24 cases (54\%).

Conclusion: Chest X-Ray images of pneumonia is more common in males with The most dominant age is $>60$ years.

Key Words: Pneumonia, chest X-ray

Latar Belakang : Infeksi saluran napas bawah akut (ISNBA) menimbulkan angka kesakitan dan kematian yang tinggi serta kerugian produktivitas kerja. ISNBA dapat dijumpai dalam berbagai bentuk, tersering adalah pneumonia. Pneumonia adalah penyakit yang banyak terjadi yang menginfeksi kira-kira 450 juta orang per tahun dan terjadi di seluruh penjuru dunia. Penyakit ini merupakan penyebab utama kematian pada semua kelompok yang menyebabkan jutaan kematian (7\% dari kematian total dunia) setiap tahun. Angka ini paling besar terjadi pada anak-anak yang berusia kurang dari 5 tahun, dan dewasa yang berusia lebih dari 75 tahun. Foto toraks merupakan modalitas yang digunakan untuk mendiagnosis banyak kondisi yang melibatkan dinding toraks, tulang toraks dan struktur yang berada di dalam kavitas toraks termasuk paru-paru, jantung dan saluran-saluran yang besar.

Tujuan : Untuk mengetahui gambaran foto toraks pada penderita pneumonia. 
Metode : Penelitian ini menggunakan jenis penelitian deskriptif retrospektif yang dilakukan pada bulan November 2015 di Bagian/SMF Radiologi FK Unsrat/ RSUP Prof. Dr. R. D. Knadou Manado

Hasil : Terdapat 44 kasus pneumonia berdasarkan diagnosis radiologis. Penderita terbanyak adalah laki-laki 24 orang (55\%), golongan umur terbanyak adalah $>60$ tahun sebanyak 12 orang (27\%), dan lokasi pneumonia terbanyak yaitu pada pulmo dextra sebanyak 24 kasus $(54 \%)$.

Kesimpulan : Gambaran foto toraks penderia pneumonia lebih banyak ditemukan pada lakilaki dengan usia yang paling dominan adalah $>60$ tahun.

Kata Kunci : Pneumonia , Foto Toraks

Infeksi saluran napas bawah akut (ISNBA) menimbulkan angka kesakitan dan kematian yang tinggi serta kerugian produktivitas kerja. ISNBA dapat dijumpai dalam berbagai bentuk, tersering adalah dalam bentuk pneumonia. Pneumonia ini dapat terjadi secara primer atau merupakan tahap lanjutan manifestasi ISNBA lainnya misalnya sebagai perluasan bronkiektasis yang terinfeksi. ${ }^{1}$

Pneumonia adalah penyakit yang banyak terjadi yang menginfeksi kira-kira 450 juta orang pertahun dan terjadi di seluruh penjuru dunia. Penyakit ini merupakan penyebab utama kematian pada semua kelompok yang menyebabkan jutaan kematian (7\% dari kematian total dunia) setiap tahun. Angka ini paling besar terjadi pada anak-anak yang berusia kurang dari lima tahun, dan dewasa yang

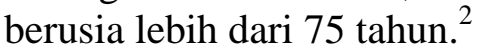

Menurut laporan dari International Vacine Access Center At The Johns Hopkins University Bloomberg School Of Public Health pada bulan November tahun 2010, penyakit pneumonia merupakan penyebab kematian nomor 1 di India, nomor 2 di Nigeria dan di Indonesia pada urutan ke 8. ${ }^{3}$ Di Indonesia, pneumonia merupakan penyebab kematian nomor 3 setelah penyakit kardiovaskular (CVD) dan tuberkulosis(TBC). Faktor soisal ekonomi yang rendah diindonesia turut pertinggi angka kematian akibat pneumonia. ${ }^{4}$
Pemeriksaan radiografi toraks atau sering disebut chest $X$-ray bertujuan menggambarkan secara radiografI organ pernapasan yang terdapat didalam rongga dada. Foto toraks digunakan untuk mendiaknosis banyak kondisi yang melibatkan dinding toraks, tulang toraks, dan struktur yang berada didalam kavitas toraks termasuk paru-paru, jantung, dan saluran-saluran yang besar. $^{5}$ Begitu banyaknya penderita pnemonia dan permintaan foto toraks di Bagian/SMF Radiologi FK UNSRAT/ RSUP PROF. Dr. R. D. Kandou Manado sehingga membuat penulis untuk meneliti mengenai gambaran foto toraks pneumonia di Bagian/SMF Radiologi FK UNSRAT / RSUP Prof. Dr. R. D. Kandou Manado periode 1 April-30 September 2015.

\section{METODE PENELITIAN}

Penelitian ini merupakan penelitian yang bersifat deskriptif retrospektif. Lokasi penelitian berada di Bagian/SMF Radiologi FK Unsrat/ RSUP Prof. Dr. R. D. Kandou Manado. Populasi penelitian adalah seluruh lembaran permintaan pemeriksaan foto toraks sedangkan sampel adalah seluruh lembaran permintaan pemeriksaan foto toraks pada pasien dengan dianosis radiologis pneumonia. Alat dan bahan yang digunakan adalah hasil expertisi foto toraks dari penderita pneumonia, literatur-literatur yang berhubungan, laptop, dan alat tulismenulis. Variabel penelitian yang diteliti yaitu, jenis kelamin, umur, dan lokasi. 
Cara kerja dari penelitian ini yaitu mengumpulkan data-data berdasarkan lembaran permintaan pemeriksaan foto toraks pada pasien dengan diagnosis radiologis pneumona. Data yang terkumpul kemdian diolah dan disajikan dalam bentuk tabel.

\section{HASIL PENELITIAN}

Berdasarkan hasil pengumpulan data sekunder yang dilakukan secara retrospektif di Bagian/SMF Radiologi FK UNSRAT/ RSUP Prof Dr. R. D. Kandou Manado pada penderita pneumonia yang dilakukan pemeriksaan foto toraks selama periode 1 April-30 September 2015 ditemukan 44 kasus dengan diagnosis radiologis pneumonia.

Tabel 1. Distribusi sampel berdasarkan jenis kelamin.

\begin{tabular}{lll}
\hline jenis kelamin & n & \% \\
\hline Laki-laki & 24 & $55 \%$ \\
Perempuan & 20 & $45 \%$ \\
Total & 44 & $100 \%$ \\
\hline
\end{tabular}

Tabel 1 menunjukan bahwa sebagian besar penderita pneumonia adalah laki-laki sebanyak 24 orang (55\%). Penderita pneumonia perempuan sebanyak 20 orang $(45 \%)$.

\begin{tabular}{lll}
\hline Umur & $\mathbf{n}$ & $\mathbf{\%}$ \\
\hline $20-30$ & 7 & $16 \%$ \\
$31-40$ & 5 & $11 \%$ \\
$41-50$ & 10 & $23 \%$ \\
$50-60$ & 10 & $23 \%$ \\
$>60$ & 12 & $27 \%$ \\
Total & 44 & $100 \%$ \\
\hline
\end{tabular}

Tabel 2 menunjukan bahwa, sebagian besar penderita pneumonia adalah kelompok umur $>60$ tahun sebanyak 12 orang $(27 \%)$. Penderita pneumonia pada kelompok umur 20-30 tahun sebanyak 7 orang (16\%). Penderita pneumonia pada kelompok umur 31-40 tahun sebanyak 5 orang (11\%). Penderita pneumonia pada kelompok umur 41-50 tahun sebanyak 10 orang (23\%), dan penderita pneumonia pada kelompok umur 50-60 tahun sebanyak 10 orang (23\%).

Tabel 3. Distribusi sampel berdasarkan lokasi.

\begin{tabular}{lll}
\hline Lokasi & $\mathbf{n}$ & $\mathbf{\%}$ \\
\hline Dextra & 24 & $54 \%$ \\
sinistra & 12 & $28 \%$ \\
Bilateral & 8 & $18 \%$ \\
Total & 44 & $100 \%$ \\
\hline
\end{tabular}

Tabel 3 menunjukan bahwa sebagian besar penderita pneumonia adalah pada bagian pulmo dekstra sebanyak 24 orang (54\%). Penderita pneumonia berdasarkan lokasi pada pulmo sinistra sebanyak 12 orang (28\%). Dan penderita pneumonia berdasarkan kedua lokasi atau bilateral sebanyak 8 orang (18\%).

\section{PEMBAHASAN}

Hasil penelitian ini didapatkan penderita pneumonia terbanyak pada laki-laki yaitu sebesar 55\%, sedangkan pada perempuan ditemukan sebanyak 45\%. Hasil penelitian ini tidak jauh berbeda dengan yang dilakukan oleh Yuda Marsono di RSU Dr. Moewardi Surakarta 2013 yaitu jumlah penderita pneumonia lebih banyak ditemukan pada laki-laki dibandingkan perempuan. Hal ini mungkin dikarenakan laki-laki sering beraktivitas diluar rumah sehingga mudah terpapar polusi dan lebih 
cenderung mengkonsumsi rokok, karena polusi udara dan asap rokok mempunyai zat kimia yang dapat memicu terjadinya infeksi saluran pernapasan. ${ }^{6}$

Berdasarkan kelompok umur, hasil penelitian ini didapatkan penderita pneumonia paling banyak pada kelompok umur $>60$ tahun sebanyak 27\%. Penderita pneumonia pada kelompok umur 20-30 tahun sebanyak 11\%. Penderita pneumonia berdasarkan kelompok umur 31-40 tahun sebanyak 23\% dan penderita pneumonia berdasarkan kelompok umur 50-60 tahun sebanyak 23\%. Penelitian ini tidak jauh berbeda dengan yang dilakukan oleh Yuda Marsono di RSUD Moewardi Surakarta 2013 dimana pasien pneumonia lebih banyak diderita pada umur 66 tahun ke atas. Hal ini disebabkan karena semakin bertambahnya umur maka sistem imun pada tubuh akan semaki menurun sehingga tubuh mudah terinfeksi. ${ }^{6}$

Berdasarkan lokasi, hasil penelitian ini didapatkan penderita pneumonia terbanyak pada pulmo dekstra yaitu sebanyak 54\%. Penderita pneumonia berdasarkan lokasi pada pulmo sinistra sebanyak 28\%. Penderita pneumonia berdasarkan lokasi dekstra dan sinistra sebanyak 18\%. Penelitian ini tidak jauh berbeda dengan yang dilakukan oleh Nur Muhamad Arjanardi di RS Kariadi Semarang dimana pada pemeriksaan radiologis ditemukan penderita pneumonia terbanyak pada paru kanan dan diikuti paru kiri. $^{7}$

\section{SIMPULAN}

Berdasarkan hasil penelitian yang dilakukan dibagian Radiologi FK UNSRAT/SMF Radiologi RSUP Prof Dr.

R. D. Kandou Manado periode 1 April-30 September 2015 mengenai gambaran foto toraks pada penderita pneumonia dapat disimpulkan bahwa:
1. Penderita pneumonia lebih banyak terjadi pada laki-laki dengan persentasi sebanyak 55\%.

2. Penderita pneumonia terbanyak pada kelompok umur $>60$ tahun dengan persentasi sebanyak $27 \%$.

3. Penderita pneumonia berdasarkan lokasi yaitu pneumonia dekstra dengan persentasi $54 \%$.

\section{SARAN}

Berdasarkan hasil penelitian, pembahasan dan kesimpulan maka penulis menyarankan:

1. Perlu dilakukan pembenahan mengenai kelengkapan data rekamedik agar dapat memudahkan para peneliti selanjutnya.

2. Perlu dilakukan upaya pencegahan mengenai penyakit pneumonia terutama pada usia yang rentan terkena agar dapat mengurangi angka kejadian.

3. Perlu penelitian lebih lanjut mengenai pneumonia dengan variabel yang berbeda.

\section{DAFTAR PUSTAKA}

1. Zul Dahlan. Pneumonia. In: Aru W Sudoyo, Bambang Setyohadi, Idrus Alwi, Marcellus Simadibrata, Siti Setiati, editors. Buku Ajara Ilmu Penyakit Dalam. Edisi V. Jakarta Pusat: Interna Publishing;2009.p.219698

2. Ruskanen, O; Lahti, E, Jennings, LC, Murdoch, DR (2014-0409).”Viral pneumonia”. Lancet377(0773):1264-75. 
3. IVAC IVAC. Pneumonia Report Card. USA: The John Hopkins University Bloomberg School Of Public Health; 2010.

4. Anwar Budiman Syaeful. 2010. Gambaran Radiologi Pneumonia pada pasien Lanjut Usia. Bagian Ilmu Radiologi RSUD Temanggung. Fakultas Kedokteran Universitas Muhammadiyah Yogyakarta.

5. Risnawati D. Gambaran Hasil foto Toraks Pada Pasien Baru di Bagian/SMF Radiologi FK UNSRAT BLU RSUP Prof. Dr. R.D Kandou Manado Periode juni-oktober 2014. Jurnal Ebm VOL.1. Manado;2015

6. Yuda Marsono. Evaluasi Penggunaan anibiotik pada pasien pneumonia dengan metode gyssens di instalasi Rawat inap Rumah Sakit umum dokter moewardi surakarta [skripsi].[universitas muhammadiyah surakarta]; 2013.

7. Nur Muhammad Arjanardi. Pola Klinis Pneumonia Komunitas Dewasa di RSUP DR. Kariadi Semarang [skripsi]. Universitas Ponegoro;2004. 